\title{
Synthesis of Acetonitrile from Syngas and Ammonia over Silica-supported Molybdenum Catalysts Modified by Silver
}

\author{
Hideaki Hamada*, Yasushi Kuwahara, Yutaka Matsuno, \\ and Katsuhiko WAKABAYASHI \\ National Chemical Laboratory for Industry, Higashi, Yatabe, \\ Tsukuba-gun, Ibaraki 305
}

(Received Sptember 18, 1986)

\begin{abstract}
Direct synthesis of acetonitrile from syngas and ammonia over silica-supported molybdenum catalysts was studied. The catalysts were prepared by impregnation of silica followed by calcination and reduction. The reduction treatment in the preparation, however, had little influence on the activity of $\mathrm{Mo} / \mathrm{SiO}_{2}$, because the reduction of Mo species on silica proceeds under the reaction atmosphere. Ag had an excellent effect on the catalyst to improve its activity and selectivity to acetonitrile. The optimum reaction temperature was between $450^{\circ} \mathrm{C}$ and $500^{\circ} \mathrm{C}$. The weight change of $\mathrm{Mo} / \mathrm{SiO}_{2}$ and $\mathrm{Mo}-\mathrm{Ag} / \mathrm{SiO}_{2}$ during reduction treatment suggested that $\mathrm{MoO}_{2}$ is the supported Mo species, regardless of whether $\mathrm{Ag}$ is added as a promoter or not. From the X-ray diffraction measurements, it was speculated that $\mathrm{MoO}_{2}$ is the active species for the formation of acetonitrile and that $\mathrm{Ag}$ has an effect of making $\mathrm{MoO}_{2}$ amorphous or more dispersed. The deactivation of the catalysts may be caused by both crystal growth of $\mathrm{MoO}_{2}$ and surface fouling.
\end{abstract}

\subsection{Introduction}

It is well known that hydrogenation of carbon monoxide gives various hydrocarbons and oxygenated compounds. Numerous studies have been made on this reaction because it is a principal reaction in $\mathrm{C}_{1}$ chemistry. $\mathrm{C}_{1}$ chemistry including heteroatoms other than oxygen (e.g. nitrogen), however, has not received much attention until recently, in spite of its importance.

In 1949, Ruhrchemie ${ }^{1)}$ got a patent to synthesize aliphatic primary amines by the addition of $0.5-$ $5 \%$ ammonia to a $\mathrm{FT}$ reaction system with $\mathrm{Fe}$ catalysts. In 1973, W. R. Grace and Co. ${ }^{2)}$ secured a patent to prepare $\mathrm{N}$-alkylamines by reaction of syngas and ammonia over $\mathrm{Fe}$ catalysts modified by Group IA, IIA, and III metals. Henrici-Olive and Olive $^{3)}$ investigated this reaction and concluded that these amines are formed through dissociation of alkyl-metal bond by ammonia. They also proposed a possible reaction mechanism of FT synthesis. Other patents concerning the synthesis of nitrogencontaining compounds from syngas and ammonia include the preparation of trimethylamine with $\mathrm{Cu}$ Cr catalysts, ${ }^{4)}$ acetamide with Rh-Mn catalysts, ${ }^{5}$ ) and methylamine and ethylamine with $\mathrm{Rh}-\mathrm{Fe}$ cat-

* To whom correspondence should be addressed. alysts. ${ }^{6)}$

Recently, Monsanto Co. got a patent for the preparation of acetonitrile from syngas and ammonia by using molybdenum catalysts.7),8) This patent is significant in that this method gives nitrogen-containing $\mathrm{C}_{2}$ compounds directly from carbon monoxide, hydrogen, and ammonia. Acetonitrile is useful as the starting material of medicines, perfumes and so on. Acetonitrile, moreover, can be converted to acrylonitrile by the reaction with formaldehyde, $\left.{ }^{9}\right)$ with methane and oxygen, ${ }^{10}$ ) or with methanol and oxygen. ${ }^{11)}$ This suggests the possibility of the production of acrylonitrile from $\mathrm{C}_{1}$ compounds.

No academic studies on this reaction, however, have been reported so far and details of this reaction are not clear. In this study, we have investigated the activity of modified molybdenum catalysts and found that silica-supported molybdenum-silver catalysts have positive activity for the formation of acetonitrile from syngas and ammonia. The effect of silver as a promoter was studied together through characterization of the catalysts.

\section{Experimental}

\subsection{Preparation of Catalysts}

The catalysts were prepared by simultaneous im- 
pregnation of silica (Davison \#57, 8-12 mesh, surface area: $300 \mathrm{~m}^{2} / \mathrm{g}$ ) with aqueous solutions of metal salts (eg. $(\mathrm{NH})_{4} \mathrm{Mo}_{7} \mathrm{O}_{24} \cdot 4 \mathrm{H}_{2} \mathrm{O}$ for $\mathrm{Mo}$, chlorides for noble metals, and nitrates for other metals), and dried with a rotary evaporator $\left(80^{\circ} \mathrm{C} 1 \mathrm{~h}\right.$, $110^{\circ} \mathrm{C} 1 \mathrm{~h}$ ). The samples were then calcined by air at $500^{\circ} \mathrm{C}$ for $5 \mathrm{~h}$, and usually reduced by passing hydrogen at $500^{\circ} \mathrm{C}$ for $3 \mathrm{~h}$.

\subsection{Reaction Procedures}

The reactions were carried out with a continuous flow reaction system at atmospheric pressure. The reactor made of Pyrex was placed in a vertical furnace. The catalyst was reduced at $500^{\circ} \mathrm{C}$ for $1 \mathrm{~h}$ before reaction. The temperature was then changed to the reaction temperature and a mixture of $\mathrm{CO}, \mathrm{H}_{2}, \mathrm{NH}_{3}$, and $\mathrm{Ar}$ (as the internal standard for analysis) was fed from cylinders at a rate of 13.6, 6.7, 25.0 , and $9.8 \mathrm{~cm}^{3} \cdot \mathrm{min}^{-1}$, respectively. $\mathrm{NH}_{3}$ from a cylinder was dried through a $\mathrm{KOH}$ column. Effluent gas was analyzed with gas chromatographs every $30 \mathrm{~min}$ by sampling with a preheated gas syringe.

The columns used were as follows: $2 \mathrm{~m}$ column, molecular sieve $5 \mathrm{~A}$, operating at $55^{\circ} \mathrm{C}$ for the analysis of $\mathrm{CO}, \mathrm{CH}_{4}$, and $\mathrm{Ar} ; 3 \mathrm{~m}$ column, $1.5 \%$ squalane/ activated charcoal, operating at $55^{\circ} \mathrm{C}$ for analysis of $\mathrm{CO}$ and $\mathrm{CO}_{2} ; 3 \mathrm{~m}$ column, $\mathrm{VZ}-10$, operating at $45^{\circ} \mathrm{C}$ for the analysis of hydrocarbons; $2 \mathrm{~m}$ column, amipak 124 , operating at $65^{\circ} \mathrm{C}$ for the analysis of acetonitrile, $\mathrm{CH}_{4}$, and other nitrogen-containing compounds.

The conversion, yield, and selectivity were defined as follows :

$$
\begin{aligned}
& \text { Conversion }(\%) \\
& \quad=\frac{\mathrm{CO} \mathrm{fed}(\mathrm{mol})-\mathrm{CO} \text { recovered }(\mathrm{mol})}{\mathrm{CO} \mathrm{fed}(\mathrm{mol})} \times 100 \\
& \text { Yield }(\%) \\
& =\frac{\text { Product produced }(\mathrm{mol}) \times \text { Carbon }}{\mathrm{CO} \mathrm{fed}(\mathrm{mol})} \times 100 \\
& \text { Selectivity }(\%)=\frac{\text { Product yield }(\%)}{\text { Conversion }(\%)} \times 100
\end{aligned}
$$

\subsection{Analysis of Catalysts}

Fresh and used catalysts were identified by using an X-ray diffractometer (Philips, Model PW-1700). Oxidation state of supported metals was analyzed by an X-ray photoelectron spectrometer (Shimadzu Mfg., Model ASIX). In this XPS experiment, Si2p peak of the silica support was used as the reference peak. A thermobalance (Cahn, Model $\mathrm{RG}$ ) was also used to get information on the weight change of the catalysts during preparation.

\section{Results and Discussion}

\subsection{Activity of $\mathrm{Mo} / \mathrm{SiO}_{2}$ Catalysts}

Monsanto's patent states the use of silica-supported $\mathrm{Mo}$ and $\mathrm{Fe}$ catalysts for the synthesis of acetonitrile from $\mathrm{CO}, \mathrm{H}_{2}$, and $\mathrm{NH}_{3}$. In a preliminary experiment, we found that silica-supported Mo and $\mathrm{Fe}$ are quite effective for acetonitrile formation. Group VIII metals other than Fe gave only hydrocarbons and $\mathrm{CO}_{2}$. Since Mo was more active than $\mathrm{Fe}$, we focused our attention on $\mathrm{Mo} / \mathrm{SiO}_{2}$ catalysts.

First, three $\mathrm{Mo} / \mathrm{SiO}_{2}$ catalysts (Mo $10 \%$ ) were prepared by changing the conditions of preparation, and their catalytic activity was measured. Products were acetonitrile, hydrocarbons (mainly $\mathrm{CH}_{4}$ ), $\mathrm{CO}_{2}$, and traces of propionitrile. Judging from the carbon material balance, there ought to have been other products of small yields, but we did not detect other compounds such as amines. Table 1 summarizes the results of reaction using the three catalysts. It is noted that there is not much difference in the activity among the three catalysts. To examine the reason, X-ray diffraction was measured for fresh and used catalysts. As can be seen from Fig. 1, Catalyst A, which has not been reduced with $\mathrm{H}_{2}$, shows the pattern of $\mathrm{MoO}_{3}$ before reaction, and the peaks of Catalyst $\mathrm{B}$ correspond to those of $\mathrm{MoO}_{2}$. This indicates that $\mathrm{Mo}$ is reduced from $\mathrm{MoO}_{3}$ to $\mathrm{MoO}_{2}$ by reduction with $\mathrm{H}_{2}$. The diffraction peaks of Catalyst $\mathrm{C}$, which has been reduced with $\mathrm{NH}_{3}$ instead of $\mathrm{H}_{2}$, are not so clear, although the pattern seems to be that of molybdenum nitrides.

\begin{tabular}{|c|c|c|c|c|c|c|c|c|c|}
\hline \multirow[b]{2}{*}{ Catalyst } & \multirow[b]{2}{*}{ Conditions of Preparation } & \multirow{2}{*}{$\begin{array}{c}\mathrm{CO} \\
\text { Conversion } \\
(\%)\end{array}$} & \multicolumn{7}{|c|}{ Selectivity $(\%)$} \\
\hline & & & $\mathrm{CH}_{3} \mathrm{CN}$ & $\mathrm{CH}_{4}$ & $\mathrm{C}_{2} \mathrm{H}_{6}$ & $\mathrm{C}_{2} \mathrm{H}_{4}$ & $\mathrm{C}_{3} \mathrm{H}_{8}$ & $\mathrm{C}_{3} \mathrm{H}_{6}$ & $\mathrm{CO}_{2}$ \\
\hline $\begin{array}{l}\text { A } \\
\text { B } \\
\text { C }\end{array}$ & $\begin{array}{l}\text { Calcination only } \\
\text { Calcination and Reduction with } \mathrm{H}_{2}\left(500^{\circ} \mathrm{C}, 3 \mathrm{~h}\right) \\
\text { Calcination and Reduction with } \mathrm{NH}_{3}\left(500^{\circ} \mathrm{C}, 10 \mathrm{~h}\right)\end{array}$ & $\begin{array}{l}16.1 \\
15.5 \\
15.3\end{array}$ & $\begin{array}{l}26.4 \\
28.8 \\
26.1\end{array}$ & $\begin{array}{l}1.6 \\
2.5 \\
1.2\end{array}$ & $\begin{array}{c}0.06 \\
0.13 \\
\text { tr }\end{array}$ & $\begin{array}{l}0.12 \\
0.26 \\
0.06\end{array}$ & $\begin{array}{l}\operatorname{tr} \\
\operatorname{tr} \\
\operatorname{tr}\end{array}$ & $\begin{array}{c}\operatorname{tr} \\
0.06 \\
\operatorname{tr}\end{array}$ & $\begin{array}{l}50.9 \\
48.9 \\
50.1\end{array}$ \\
\hline
\end{tabular}

In spite of the differences in diffraction patterns before reaction, both Catalyst $\mathrm{A}$ and $\mathrm{B}$ showed the pattern of $\mathrm{MoO}_{2}$ after being used in $1 \mathrm{~h}$ reaction. It is concluded, therefore, that $\mathrm{Mo}$ exists as $\mathrm{MoO}_{2}$ in the working state, regardless of whether the

Table 1 Activity* of $\mathrm{Mo} / \mathrm{SiO}_{2}$ Catalysts

* Reaction temperature : $450^{\circ} \mathrm{C}$, Catalyst : $\mathrm{Mo} / \mathrm{SiO}_{2}(\mathrm{Mo} 10 \%) 3 \mathrm{~cm}^{3}$. The data were obtained at $1 \mathrm{~h}$ on stream. 


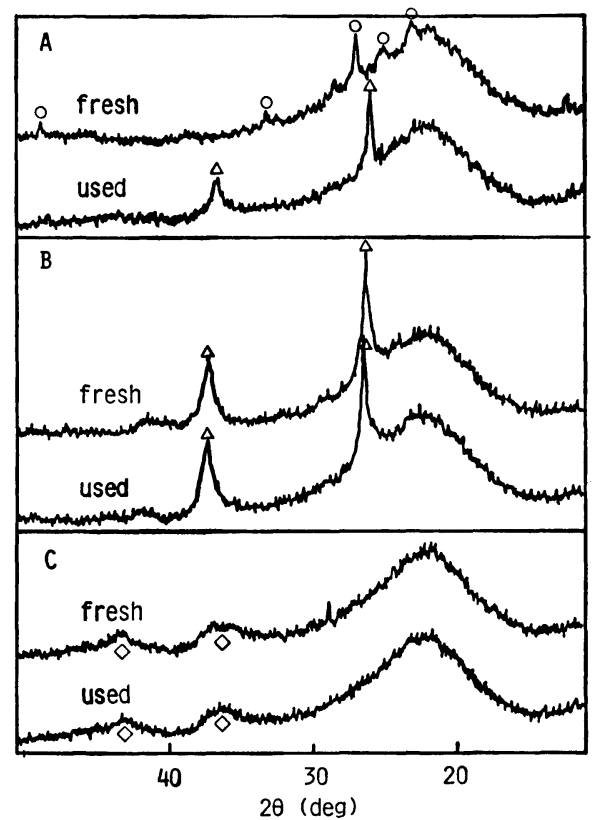

$\bigcirc: \mathrm{MoO}_{3}, \triangle: \mathrm{MoO}_{2}, \diamond:$ Mo nitrides Catalyst $\mathrm{A}, \mathrm{B}$, and $\mathrm{C}$ are listed in Table 1.

Fig. 1 X-Ray Diffractograms of $\mathrm{Mo} / \mathrm{SiO}_{2}$ Catalysts

catalyst is reduced or not before use. This is probably the reason why little difference in activity was observed between the two catalysts. In fact, a slight increase in the yield of acetonitrile with time on stream was observed with Catalyst $\mathrm{A}$, in the early stage of the reaction. This may be explained by the reduction of $\mathrm{MoO}_{3}$ to active $\mathrm{MoO}_{2}$ species under the reaction atmosphere. In contrast, the yield decreased monotonously with time on stream with Catalyst B.

In the case of Catalyst $\mathrm{C}, \mathrm{MoO}_{2}$ peaks were not observed after use, and yet it had almost the same catalytic activity as Catalyst $\mathrm{A}$ and $\mathrm{B}$. The reason is not clear. One possibility is that $\mathrm{MoO}_{2}$ is in amorphous or highly dispersed state, as in the case of $\mathrm{Mo}-\mathrm{Ag} / \mathrm{SiO}_{2}$ catalysts, which will be stated later. Another is that molybdenum nitrides are also active species.

\subsection{Activity of $\mathrm{Mo} / \mathrm{SiO}_{2}$ Catalysts Modified with Other Metals}

In order to improve catalytic activity, series of silica-supported Mo-containing bimetallic catalysts (Mo 5\%) were prepared by simultaneous impregnation method. The results of reaction are given in Table 2.

The addition of alkali and alkaline earth metals to $\mathrm{Mo} / \mathrm{SiO}_{2}$ resulted in the decrease of $\mathrm{CO}$ conversion and selectivity to acetonitrile. The Group VIII metals have no beneficial effect, although $\mathrm{Rh}$ improves the selectivity to a little degree. On the other hand, Ag shows a striking effect as a promoter because the selectivity to acetonitrile is increased by about $50 \%$. Our experiments also indicate that $\mathrm{Cu}$ improves the selectivity from 35 to $40 \%$. While it is known that $\mathrm{Cu}$ is a good promoter, ${ }^{7)}$ there has not been a report yet on the prominent effect of $\mathrm{Ag}$.

\subsection{Effect of Ag as a Promoter}

In order to elucidate the effect of $\mathrm{Ag}, \mathrm{Mo}-\mathrm{Ag} / \mathrm{SiO}_{2}$ catalysts having different $\mathrm{Ag} / \mathrm{Mo}$ molar ratios were prepared. The Mo loading was fixed at $10 \mathrm{wt} \%$. The activity of these catalysts is shown in Fig. 2. The CO conversion, acetonitrile yield, and the selectivity to acetonitrile all increased as the $\mathrm{Ag} / \mathrm{Mo}$ ratio was increased from 0 to 0.2 . No increase in activity, however, was observed beyond $\mathrm{Ag} / \mathrm{Mo}=$ 0.2 , showing that a small amount of $\mathrm{Ag}$ suffices to improve the catalytic performance. The same effect was also observed when Mo loading was $5 \mathrm{wt} \%$.

\subsection{Effect of Reaction Conditions}

The effect of reaction temperature on $\mathrm{Mo}-\mathrm{Ag} / \mathrm{SiO}_{2}$

Table 2 Activity*1 of $\mathrm{Mo} / \mathrm{SiO}_{2}$ Catalysts Modified with Other Metals

\begin{tabular}{|c|c|c|c|c|c|c|c|c|}
\hline \multirow{2}{*}{ Catalyst*2 } & \multirow{2}{*}{ CO Conversion (\%) } & \multicolumn{7}{|c|}{ Selectivity (\%) } \\
\hline & & $\mathrm{CH}_{3} \mathrm{CN}$ & $\mathrm{CH}_{4}$ & $\mathrm{C}_{2} \mathrm{H}_{6}$ & $\mathrm{C}_{2} \mathrm{H}_{4}$ & $\mathrm{C}_{3} \mathrm{H}_{8}$ & $\mathrm{C}_{3} \mathrm{H}_{6}$ & $\mathrm{CO}_{2}$ \\
\hline Mo & 23.2 & 35 & 4.0 & 0.30 & 0.43 & 0.04 & 0.17 & 47 \\
\hline Mo-Li & 20.4 & 26 & 2.0 & 0.10 & 0.15 & $\operatorname{tr}$ & $\mathrm{tr}$ & 6.5 \\
\hline $\mathrm{Mo}-\mathrm{Na}$ & 17.1 & 23 & 1.3 & 0.06 & 0.12 & $\operatorname{tr}$ & $\operatorname{tr}$ & 15 \\
\hline Mo-K & 13.7 & 15 & 0.4 & $\mathrm{tr}$ & $\operatorname{tr}$ & $\operatorname{tr}$ & $\operatorname{tr}$ & 43 \\
\hline Mo-Rb & 14.4 & 17 & 0.4 & $\mathrm{tr}$ & 0.07 & $\operatorname{tr}$ & tr & 42 \\
\hline Mo-Cs & 15.8 & 13 & 0.4 & $\operatorname{tr}$ & $\operatorname{tr}$ & $\operatorname{tr}$ & $\operatorname{tr}$ & 33 \\
\hline Mo-Mg & 17.9 & 23 & 1.6 & 0.06 & 0.17 & $\operatorname{tr}$ & $\operatorname{tr}$ & 32 \\
\hline Mo-Ca & 19.0 & 31 & 2.6 & 0.16 & 0.26 & $\operatorname{tr}$ & $\mathrm{tr}$ & 38 \\
\hline Mo-Co & 20.2 & 21 & 2.6 & 0.30 & 0.79 & 0.05 & 0.30 & - \\
\hline Mo-Ni & 45.8 & 12 & 23 & 3.43 & 1.51 & 0.48 & 1.14 & - \\
\hline Mo-Ru & 16.1 & 25 & 2.6 & 0.12 & 0.37 & $\operatorname{tr}$ & $\operatorname{tr}$ & 42 \\
\hline Mo-Rh & 25.4 & 38 & 14 & 2.72 & 0.91 & 0.36 & 0.47 & 33 \\
\hline $\mathrm{Mo}-\mathrm{Cu}$ & 20.9 & 40 & 3.9 & 0.29 & 0.53 & tr & $\mathrm{tr}$ & 26 \\
\hline Mo-Ag & 25.9 & 45 & 6.6 & 0.70 & 0.89 & 0.12 & 0.39 & 40 \\
\hline Mo-Au & 14.0 & 18 & 1.9 & 0.07 & 0.29 & $\operatorname{tr}$ & $\operatorname{tr}$ & 57 \\
\hline
\end{tabular}

*1 Reaction temperature $: 450^{\circ} \mathrm{C}$, Catalyst amount : $15 \mathrm{~cm}^{3}$. The data were obtained at $3 \mathrm{~h}$ on stream.

*2 Mo $5 \mathrm{wt} \%, \mathrm{M} / \mathrm{Mo}$ (molar ratio) $=1 / 3(\mathrm{Na} / \mathrm{Mo}=1 / 10)$. 


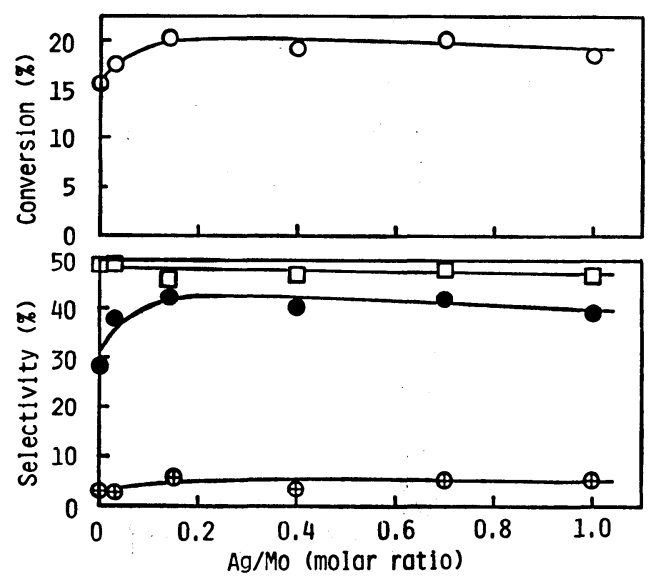

$\mathrm{O}: \mathrm{CO}$ conversion, $\square$ : $\mathrm{CO}_{2}$ selectivity, Reaction temperature : $450^{\circ} \mathrm{C}$

Catalyst : $\mathrm{Mo}-\mathrm{Ag} / \mathrm{SiO}_{2}$ (Mo 10\%) $3 \mathrm{~cm}^{3}$

The data were obtained at $1 \mathrm{~h}$ on stream.

Fig. 2 Effect of $\mathrm{Ag}$ as a Promoter

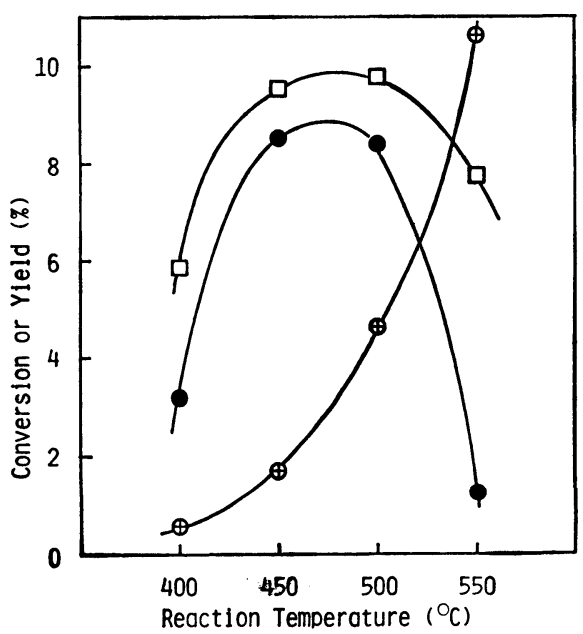

: Acetonitrile yield,

$\bigoplus$ : Hydrocarbon yield

Catalyst : $\mathrm{Mo}-\mathrm{Ag} / \mathrm{SiO}_{2}(\mathrm{Mo} 5 \%, \mathrm{Ag} / \mathrm{Mo}=1 / 7) 15 \mathrm{~cm}^{3}$

The data were obtained after stabilizing the catalyst.

Fig. 3 Effect of Reaction Temperature

(Mo $5 \%, \mathrm{Ag} / \mathrm{Mo}=1 / 7$ ) is shown in Fig. 3. The reaction data were collected after stabilizing the catalyst by conducting a reaction for $22 \mathrm{~h}$. It can be seen that acetonitrile yield reached a maximum at about $450^{\circ} \mathrm{C}$, whereas hydrocarbons were formed in high yields as the reaction temperature was increased. Moreover, high temperature caused the decomposition of $\mathrm{NH}_{3}$ producing a great amount of $\mathrm{N}_{2}$. From these observations, it is concluded that the optimum reaction temperature is between $450^{\circ} \mathrm{C}$ and $500^{\circ} \mathrm{C}$.

It is often possible to speculate reaction intermediates by examining the variation of product yields with reaction time. The effect of contact time is

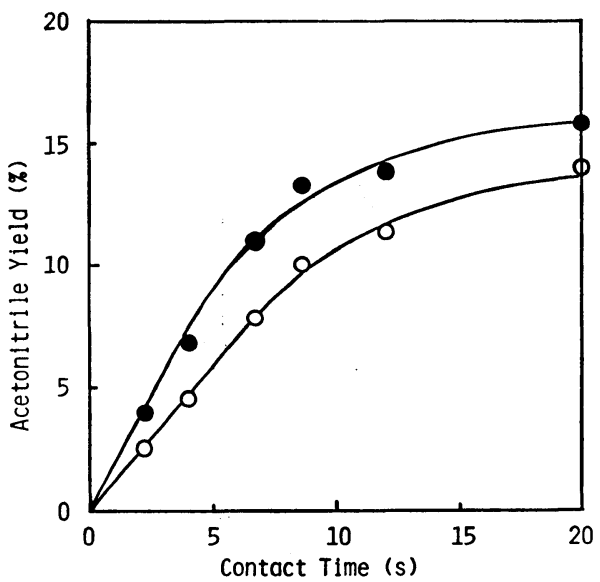

$\mathrm{O}: \mathrm{Mo} / \mathrm{SiO}_{2}$ (Mo 5\%),

- : $\mathrm{Mo}-\mathrm{Ag} / \mathrm{SiO}_{2}(\mathrm{Mo} 5 \%, \mathrm{Ag} / \mathrm{Mo}=3 / 100)$

Reaction temperature : $450^{\circ} \mathrm{C}$

The data were obtained at $1 \mathrm{~h}$ on stream.

Fig. 4 Effect of Contact Time

shown in Fig. 4. Within the range of contact time of $7 \mathrm{~s}$, the yield of acetonitrile increased proportionally with contact time. While methylamine has been suspected to be the reaction intermediate because the conversion of methylamine to acetonitrile is known, ${ }^{12)}$ we could not detect any other nitrogen-containing products over the whole range of contact time. Figure 4 also shows the higher activity of $\mathrm{Mo}-\mathrm{Ag} / \mathrm{SiO}_{2}$ as compared to that of $\mathrm{Mo} / \mathrm{SiO}_{2}$.

\subsection{Characterization of Catalysts}

To elucidate the chemical state of Mo in the catalysts, the weight changes of the catalysts resulting from reduction treatment in the preparation were measured. A sample of about $0.4 \mathrm{~g}$, impregnated and then calcined, was put in a thermobalance and the weight change by reduction with flowing hydrogen at $500^{\circ} \mathrm{C}$ for $3 \mathrm{~h}$ was recorded. The weight loss measured was $3.13 \mathrm{mg}$ for $\mathrm{Mo} / \mathrm{SiO}_{2}$ (Mo 5\%) and $2.98 \mathrm{mg}$ for $\mathrm{Mo}-\mathrm{Ag} / \mathrm{SiO}_{2}$ (Mo 5\%, $\mathrm{Ag} / \mathrm{Mo}=3 / 100)$. The calculated weight losses based on the assumption that $\mathrm{Mo}$ and $\mathrm{Ag}$ are in the form of $\mathrm{MoO}_{3}$ and $\mathrm{Ag}_{2} \mathrm{O}$ before reduction, and in the form of $\mathrm{MoO}_{2}$ and $\mathrm{Ag}$ metal after reduction, were $3.13 \mathrm{mg}$ for $\mathrm{Mo} / \mathrm{SiO}_{2}$ and $3.19 \mathrm{mg}$ for $\mathrm{Mo}-\mathrm{Ag} / \mathrm{SiO}_{2}$. As the agreement between the calculated and experimental values is quite satisfactory, it is evident that Mo exists as $\mathrm{MoO}_{2}$ after reduction, regardless of whether Ag is added as a promoter or not. Thus no difference in the oxidation state of Mo was observed between $\mathrm{Mo} / \mathrm{SiO}_{2}$ and $\mathrm{Mo}-\mathrm{Ag} / \mathrm{SiO}$.

The oxidation state of Mo at the surface was analyzed by X-ray photoelectron spectroscopy. The binding energy was corrected based on the 


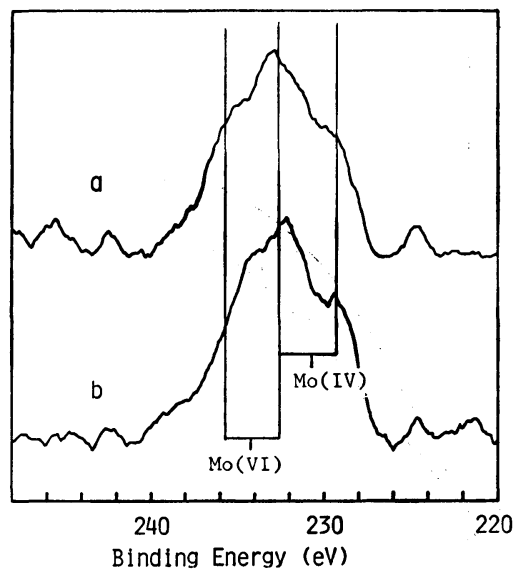

a : $\mathrm{Mo} / \mathrm{SiO}_{2}$ (Mo 5\%),

b : $\mathrm{Mo}-\mathrm{Ag} / \mathrm{SiO}_{2}(\mathrm{Mo} 5 \%, \mathrm{Ag} / \mathrm{Mo}=3 / 100)$

Fig. 5 XPS Spectra of $\mathrm{Mo} / \mathrm{SiO}_{2}$ and $\mathrm{Mo}-\mathrm{Ag} / \mathrm{SiO}_{2}$ in the Mo3d Region

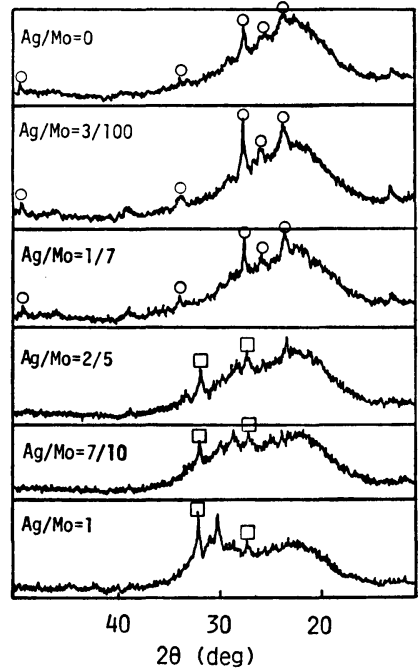

$\bigcirc: \mathrm{MoO}_{3}, \square: \mathrm{Ag}_{2} \mathrm{MoO}_{4}$

The samples have been impregnated and calcined by air at $500^{\circ} \mathrm{C}$ for $5 \mathrm{~h}$.

Fig. 6 X-Ray Diffractograms of $\mathrm{Mo}-\mathrm{Ag} / \mathrm{SiO}_{2}$ Catalysts (Mo 10\%) after Calcination

Si2p reference peak $(103.6 \mathrm{eV})$. Figure 5 indicates that surface $\mathrm{Mo}$ is a mixture of $\mathrm{Mo}(\mathrm{VI})$ and $\mathrm{Mo}(\mathrm{IV})$ in both $\mathrm{Mo} / \mathrm{SiO}_{2}$ and $\mathrm{Mo}-\mathrm{Ag} / \mathrm{SiO}{ }_{2}$. It might be seen that the intensity of $\mathrm{Mo}(\mathrm{IV})$ is a little greater for $\mathrm{Mo}-\mathrm{Ag} / \mathrm{SiO}_{2}$, which is not so convincing. The catalyst samples in this measurement were reduced in situ within the XPS chamber at $300^{\circ} \mathrm{C}$ for $1 \mathrm{~h}$, and yet there is no guarantee that the reduction would be complete. Thus, no useful information on the effect of $\mathrm{Ag}$ was obtained.

X-ray diffractograms of a series of $\mathrm{Mo}-\mathrm{Ag} / \mathrm{SiO}$ catalysts (Mo 10\%) during the preparation are shown in Figs 6, 7, and 8. In Fig. 6 showing the diffractograms after calcination, the peaks cor-

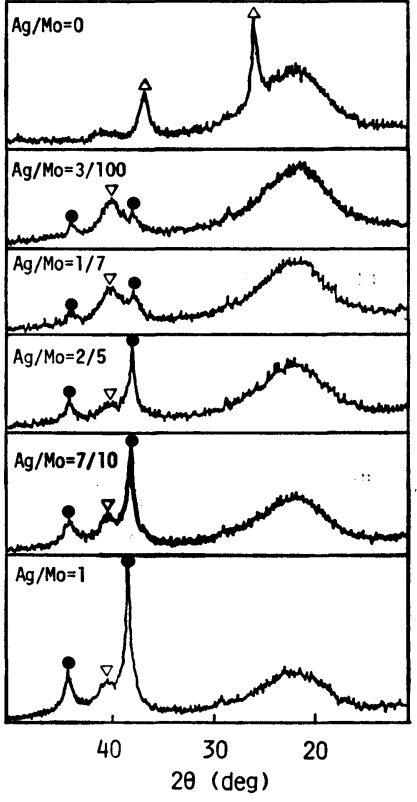

$\triangle: \mathrm{MoO}_{2}$,

: Ag metal, $\nabla:$ Mo metal

The samples have been impregnated, calcined, and reduced by hydrogen at $500^{\circ} \mathrm{C}$ for $3 \mathrm{~h}$.

Fig. 7 X-Ray Diffractograms of $\mathrm{Mo}-\mathrm{Ag} / \mathrm{SiO}_{2}$ Catalysts (Mo 10\%) after Reduction

responding to $\mathrm{MoO}_{3}$ are observed when $\mathrm{Ag} / \mathrm{Mo}$ is less than 1/7 and that the pattern of $\mathrm{Ag}_{2} \mathrm{MoO}_{4}$ is observed instead of that of $\mathrm{MoO}_{3}$ when the amount of $\mathrm{Ag}$ is more than that value. Small peaks other than those of $\mathrm{Ag}_{2} \mathrm{MoO}_{4}$ also appear, although the assignment is unknown. These observations suggest that mixed oxides from Mo and Ag are formed by the calcination.

Figure 7 indicates the diffractograms after reduction following calcination. $\mathrm{Mo} / \mathrm{SiO}_{2}$ shows the pattern of $\mathrm{MoO}_{2}$. It should be noted, however, that the peaks of $\mathrm{MoO}_{2}$ are replaced by those of Mo and Ag metals when $\mathrm{Ag}$ is added to $\mathrm{Mo} / \mathrm{SiO}_{2}$. This suggests that Ag has the effect of promoting the reduction of Mo to the lower oxidation state. Nevertheless, it is unreasonable, from the thermobalance experiments, to assume that all of the Mo atoms in $\mathrm{Mo}-\mathrm{Ag} / \mathrm{SiO}_{2}$ are in the form of Mo metal. Probably, most of the Mo atoms exist as $\mathrm{MoO}_{2}$ in amorphous or highly dispersed state in the presence of Ag promoter. It may be speculated, therefore, that $\mathrm{MoO}_{2}$ is the active species for the conversion of syngas and $\mathrm{NH}_{3}$ to acetonitrile, and that Ag makes $\mathrm{MoO}_{2}$ amorphous or highly dispersed. This conclusion is supported by $\mathrm{X}$-ray diffractograms in Fig. 8, showing that the peaks of $\mathrm{MoO}_{2}$ replace those of Mo metal rapidly during the reaction. Diffractograms in Fig. 8 further show that the intensity of $\mathrm{MoO}_{2}$ peaks of $\mathrm{Mo} / \mathrm{SiO}_{2}$ is larger than 


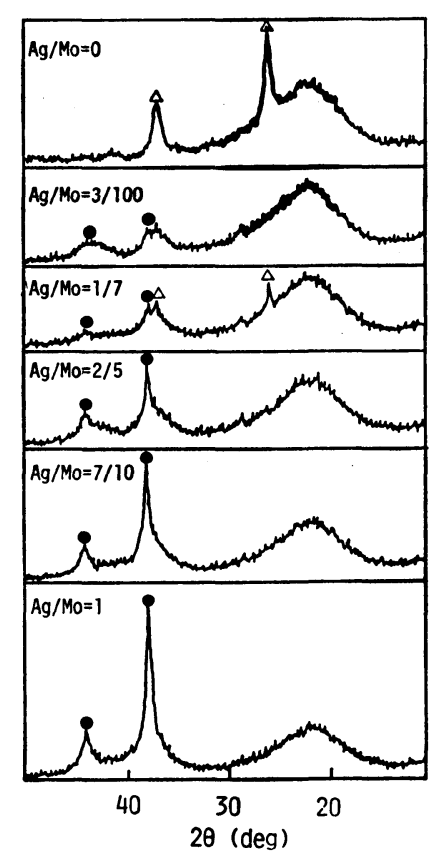

$\triangle: \mathrm{MoO}_{2}, \quad \bigcirc:$ Ag metal

The samples have been used as catalysts for $1 \mathrm{~h}$ at $450^{\circ} \mathrm{C}$.

Fig. 8 X-Ray Diffractograms of $\mathrm{Mo}-\mathrm{Ag} / \mathrm{SiO}_{2}$ Catalysts (Mo 10\%) after Use

those of $\mathrm{Mo}-\mathrm{Ag} / \mathrm{SiO}_{2}$.

\subsection{Deactivation of Catalysts}

The change in catalytic activity of $\mathrm{Mo} / \mathrm{SiO}_{2}(\mathrm{Mo}$ $5 \%$ ) and $\mathrm{Mo}-\mathrm{Ag} / \mathrm{SiO}_{2}$ (Mo $5 \%, \mathrm{Ag} / \mathrm{Mo}=3 / 100$ ) with time on stream is shown in Fig. 9. The activity deteriorates gradually with time. The X-ray diffractogram of $\mathrm{Mo} / \mathrm{SiO}_{2}$ indicates the appearance of $\mathrm{MoO}_{2}$ peaks after reaction of $28 \mathrm{~h}$, though no diffraction peaks are detected for fresh $\mathrm{Mo} / \mathrm{SiO}_{2}$. This variance suggests the relationship between the catalyst deactivation and the appearance of $\mathrm{MoO}_{2}$ diffraction peaks, namely, the growth of $\mathrm{MoO}_{2}$ crystals.

With respect to the difference in the activity observed between $\mathrm{Mo} / \mathrm{SiO}_{2}$ and $\mathrm{Mo}-\mathrm{Ag} / \mathrm{SiO}_{2}$, Fig. 9 serves to show that the activity of the latter is higher than that of the former in the early stage of reaction. With time on stream, however, the difference diminishes. As no diffraction peaks cor-

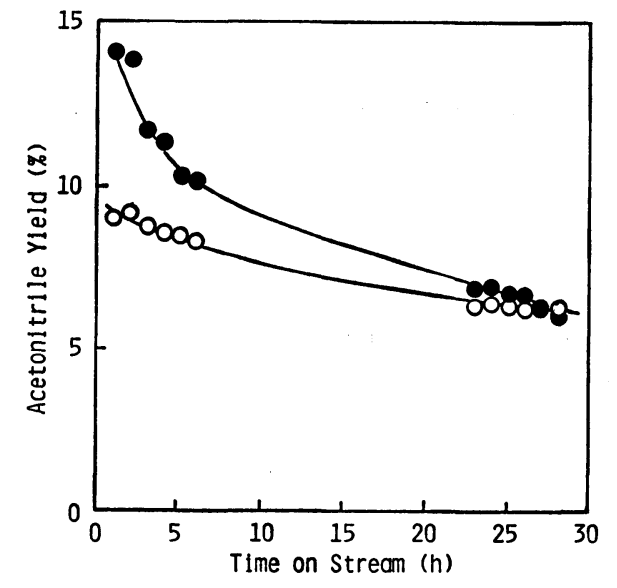

$\mathrm{O}: \mathrm{Mo} / \mathrm{SiO}_{2}$ (Mo $5 \%$ ),

- : $\mathrm{Mo}-\mathrm{Ag} / \mathrm{SiO}_{2}$ (Mo $\left.5 \%, \mathrm{Ag} / \mathrm{Mo}=3 / 100\right)$

Reaction temperature : $450^{\circ} \mathrm{C}$, Catalyst amount: $15 \mathrm{~cm}^{3}$

Fig. 9 Variation of Catalytic Activity with Time on Stream

responding to $\mathrm{MoO}_{2}$ was observed for $\mathrm{Mo}-\mathrm{Ag} / \mathrm{SiO}_{2}$ after reaction of $28 \mathrm{~h}$, the crystal growth of $\mathrm{MoO}_{2}$ is probably not the sole factor of catalyst deactivation.

The regeneration of the catalysts by reduction at $500^{\circ} \mathrm{C}$ for $3 \mathrm{~h}$ was partially successful. As no change in the X-ray diffractograms were observed, surface fouling may be one of the factors of catalyst deactivation. This might explain the small difference in activity between $\mathrm{Mo} / \mathrm{SiO}_{2}$ and $\mathrm{Mo}-\mathrm{Ag} / \mathrm{SiO}_{2}$ after reaction of $28 \mathrm{~h}$, in spite of the difference in the $\mathrm{X}$-ray diffraction patterns.

\section{References}

1) DBP 904,891 (1949).

2) U. S. $3,726,926$ (1973).

3) Henrici-Olive, G., Olive, S., J. Mol. Catal., 4, 379 (1978).

4) U. S. $3,410,904$ (1968).

5) Japan. Kokai 81 115,748.

6) Japan. Kokai $81 \quad 120,644$

7) U. S. 4,058,548 (1977).

8) Japan. Kokai 77 7,923.

9) U. S. $3,634,487$ (1972).

10) B. P. 1,493,771 (1976).

11) Japan. Kokai $8171,056$.

12) Henrici-Olive, G., Olive, S. Angev. Chem. Int. Ed. Engl., 17, 862 (1978). 


\title{
シリカ担持銀旍モリブデ触媒による合成ガスとアンモニアからのアセトニトリル合成
}

\author{
浜田秀昭, 桑原 靖, 松野 豊, 若林勝彦 \\ 化学技術研究所, 305 茨城県筑波郡谷田部町東 1-1
}

シリカ担持モリブデン系触媒による合成ガスとアンモニアか らの直接アセトニトリル合成について触媒調製条件, 助触媒の 影響を調べた。

まず, $\mathrm{Mo} / \mathrm{SiO}_{2}$ 触媒について調製条件の影響を調べた。触 媒は，モリブデン酸アンモニウム水溶液をシリカに含浸し空気 焼成後還元して調製した。本反応の主生成物はアセトニトリル， 二酸化炭素および 炭化水素類であった。空気焼成のみの 触媒 $\mathrm{A}$, 空気焼成後水素還元した触媒 $\mathrm{B}$, 空気焼成後アンモニア還 元した触媒 Cの三つの触媒の反応結果を Table 1 に示したが, ほとんど違いは認められなかった。この原因を調べるため触媒 の反応前後の X線回折をとり Fig. 1 に示した。触媒 B は反応 前後とも $\mathrm{MoO}_{2}$ のパターンを示すのに対し, 触媒Aは反応前 は $\mathrm{MoO}_{3}$, 反応後は $\mathrm{MoO}_{2}$ のパターンを示した。触媒 $\mathrm{A}$ は反応 中に還元されて触媒 $\mathrm{B}$ と同じく $\mathrm{MoO}_{2}$ が担持されている形態 になるため, 反応結果に変化がないものと理解された。このこ とは，触媒 Bの活性変化が単純に低下しないことからも支持さ れる。

次に, $\mathrm{Mo} / \mathrm{SiO}_{2}$ に対して第二金属成分を添加しその効果を 調べた結果を Table 2 に示す。アルカリ金属, アルカリ土類 金属はアセトニトリル生成活性選択性を低下させ好ましくな く，第 8 族金属もほぼ同様の結果であった。しかし，Ag はア セトニトリル生成活性を上げると同時に選択率も50\% 增大さ せる効果があることが分かった。 Ag の助触媒効果については いまだ報告はない。Fig. 2 に Ag の添加量の影響を示したが，
Ag はほんの少量で効果を現すことが分かる。Fig. 3 に示し た反応温度の影響から,アセトニトリル生成の最適温度は 450$500^{\circ} \mathrm{C}$ であった。また，接触時間の影響を示した Fig. 4 で は，ある範囲内で収率と比例関係にあった。

$\mathrm{Ag}$ の効果を調べるため, 種々の触媒分析を行った。熱天秤 による還元処理での重量変化から $\mathrm{Mo} / \mathrm{SiO}_{2}, \mathrm{Mo}-\mathrm{Ag} / \mathrm{SiO}_{2}$ い ずれの触媒においても水素還元で $\mathrm{Mo}$ は $\mathrm{MoO}_{2}$ の形となって おり,一方 Fig. 5 に示した XPS 測定でも表面での Mo の 価数に Ag の影響は認められなかった。しかし, Figs. 6, 7,8 に示したX線回折測定から Ag の効果が明らかとなった。Fig. 6 は空気焼成後のX線回折図であるが, Ag と Mo は複合酸化 物を形成する。Fig. 7 は水素還元後の回折図であり, Ag がな いときには $\mathrm{MoO}_{2}, \mathrm{Ag}$ が存在すると $\mathrm{Mo}$ 金属と $\mathrm{Ag}$ 金属の 回折ピークが認められる。しかし他の情報から $\mathrm{Ag}$ が存在す る場合でも $\mathrm{Mo}$ は $\mathrm{MoO}_{2}$ の形で存在していると考えられ，お そらく $\mathrm{Ag}$ の存在は $\mathrm{MoO}_{2}$ を無定形か高分散状態にする働き をしているすのと推定された。Mo 金属が反応活性種となって いないことは Fig. 8 の反応後の回折図でそのピークが完全に 消失していることからも確かめられた。

触媒活性の経時变化を Fig. 9 亿示すが，活性は時間ととも に低下している。X線回折測定から $\mathrm{MoO}_{2}$ の結晶成長が触媒 劣化と関係があることが示唆されるが, 表面への炭素質あるい は有機物の 沈着もひとつの原因になっているものと考えられ た。

\section{Keywords}

Acetonitrile, Ammonia, Molybdenum catalyst, Silver, Syngas, X-ray diffraction 